Article

\title{
Transformative Pedagogy, Black Theology and Participative forms of Praxis
}

\author{
Anthony G. Reddie \\ Department of Philosophy, Practical and Systematic Theology, The University of South Africa, \\ Pretoria P.O. Box 392, South Africa; agreddie@gmail.com
}

Received: 13 September 2018; Accepted: 16 October 2018; Published: 18 October 2018

check for updates

\begin{abstract}
This paper outlines the development of a form of scholarship that seeks to bring together transformative modes of pedagogy that have become commonplace in Christian religious education alongside the liberative themes to be found in Black theology. The paper summarises the significant contributions of Paulo Freire to transformative pedagogy and conscientization as the first stage in this developing work. This formative analysis is then followed by reflections on the significant developments in religious education by and for Black people, principally in the US. In the final part of the paper, I describe my own participative approaches to Black theology by means of transformative pedagogy, which utilises interactive exercises as a means of combining the insights of the aforementioned ideas and themes into a transformative mode of teaching and learning.
\end{abstract}

Keywords: Paulo Freire; transformative pedagogy; Christian education; Black religious education; participative Black Theology

\section{Introduction}

My scholarship has always existed at the nexus of Black theology and Christian education. ${ }^{1}$ In terms of the latter, my work has been concerned with using the frameworks of radical, liberative education as a conduit for undertaking Black theological focussed work. The purpose of this scholarship is the conscientization and Christian formation of ordinary lay people and those training for public, authorized, Christian ministry.

My participative approach to undertaking Black theological scholarship is one that seeks to use models of experiential learning, such as exercises and games, role-play and drama as an interactive means of engaging with adult learners, in order that they can be impacted by, learn from and contribute to the development of new knowledge concerning the theory and practice of Black Theology. ${ }^{2}$

\section{Christian Education as the Practice of Freedom}

The development of my work as a Practical theologian comes from within the more specific discipline of Christian education. The term 'Christian Education' can be defined and understood in a variety of ways. Jeff Astley and Colin Crowder provide a helpful starting point for a definition and a rationale for Christian Education. The authors describe Christian Education as:

The phrase ... often used quite generally to refer to those processes by which people learn to become Christian and to be more Christian, through learning Christian beliefs, attitudes,

1 Portions of this article have been used in a previously published piece of work. I can confirm that I own the copyright on the previous piece of work.

2 Extensive examples of this work can be found in the following: all by Reddie (2005, 2006a, 2006b, 2008). 
values, emotions and dispositions to engage in Christian actions and to be open to Christian experiences. $^{3}$

In using Christian education as a means exploring anti-racist discipleship I am concerned with providing an accessible framework for the radical re-interpretation of the Christian faith for the transformation of ordinary people.

Paulo Freire's ground breaking work in devising appropriate pedagogies for teaching marginalized and oppressed peoples is legendary. ${ }^{4}$ Freire developed a philosophy of education that challenged poor and oppressed people to reflect upon their individual and corporate experiences and begin to ask critical questions about the nature of their existence. The radical nature of this critical approach to the task of teaching and learning brought Freire to the attention of the military government in Brazil in 1964. He was subsequently imprisoned and then exiled. In exile, he began to refine further his educational philosophy and method.

He came to international attention with the publication of his first book Pedagogy of the Oppressed, ${ }^{5}$ which laid the foundations for a seismic shift in the whole conception of how poor, oppressed and marginalized people might be educated. The importance of Paulo Freire cannot be overstated. In developing a rigorous and critical approach to the task of educating those who are poor and oppressed, Freire created an essential template by which Religious educators and Practical theologians might re-conceptualise their task. One of Freire's central concepts was that of 'conscientization'. This is a process where poor and oppressed people become politically aware of the circumstances in which they live and the ways in which their humanity is infringed upon and blighted by the often dehumanising contexts that surround them. ${ }^{6}$ Allen J. Moore commenting on this aspect of Freire's work says.

Conscientization in Freire's work is apparently both an individual experience and a shared experience of a people who are acting together in history. A way of life is not determined from thinking about the world but is formed from the shared praxis. In this critical approach to the world, basic attitudes, values, and beliefs are formed and a people are humanized or liberated. Conscientization, therefore, leads to a life lived with consciousness of history, a life lived that denounces and transforms this history in order to form a new way of life for those who are oppressed. ${ }^{7}$

Freire's approach to education has opened up new vistas for Religious educators, along with Pastoral and Practical theologians. Freire's work, with its emphasis on human transformation and self-actualization, has become the template by which various models of critical pedagogy, be they liberation theologies, liberative models of psychology or transformative education, have sought to develop differing perspectives on the task of socio-cultural and political development. ${ }^{8}$ In my scholarship, I have attempted to combine the radical intent of transformative education arising from the Freirerian tradition with Black liberation theology in order to develop a more participative and interactive mode of theo-pedagogical engagement that moves intellectual discourse beyond mere theorizing into more praxis based forms of practice.

\section{Transformative Christian Education in the Black Experience}

Since the late 1960s, Black religious educators have sought to provide an alternative means of understanding the Christian faith. This counter proposition has refuted notions of entitlement and privilege and the constructs that are predicated on White normality. These models of Christian

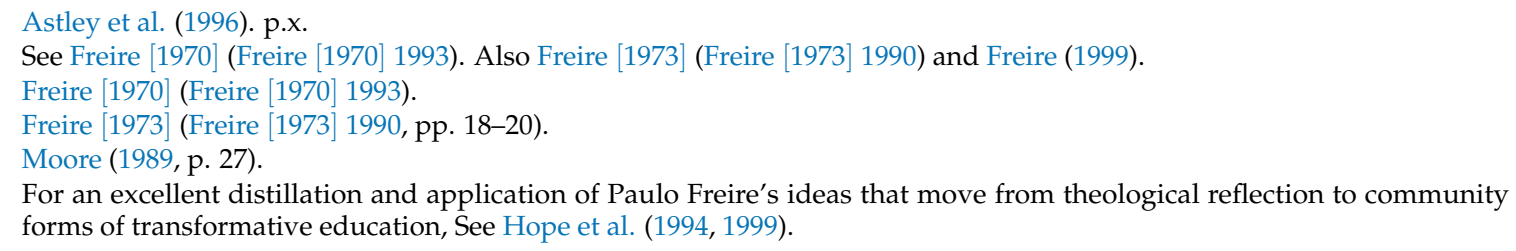


socialization and formation seek to affirm Black experience and embodiment, focussing on Black identities and the existential quest for self determination. What has underpinned these radical counter assertive models of Christian, inspired teaching and learning is the prophetic stance of Black liberation theology, the model of theological articulation that underpins this work.

\subsection{Black Theology}

When speaking of Black theology, I am referring to a specific self-named enterprise of re-interpreting the meaning of God as revealed in Christ, in light of existential Black experience. The point of departure in Black theology is the existential and ontological reality of Blackness and the Black experience, namely, how does feel to be a Black body in the world and what is the theological meaning of this experience? Where is God in the midst of the existential crisis as Black bodies seek to feel and to be whole in a world where authentic being is often denied them? ${ }^{9}$

Black theology is a theology of liberation and is not simply any theology undertaken by Black people. From earliest iterations, Black theology was conceived as a form of liberation theology. ${ }^{10}$ Like all forms of liberation theology, Black theology focusses its concerns on ortho-praxis rather than orthodoxy. The commitment to the former as opposed to the latter is partly a result of a form of existential pragmatism, in which the practical challenges of resisting racism and trying to fight for Black self determination has taken precedence over historical arguments on what constitutes correct understandings of God. ${ }^{11}$ Traditionally, Black theology's interest in say doctrine, has been rooted in the extent to which particular teachings about God in Christ, lend themselves to praxiological struggle, or do they promote passivity or even worse, utter indifference? ${ }^{12}$

The additional reason Black theology has eschewed a concern for orthodoxy results from the historical realisation that there has been little evidence within White Euro-American Christianity that authorized and supposedly, 'correct' teaching, has any substantive relationship with ethical, non-racist behaviour. ${ }^{13}$

Black theology, therefore, has often adopted a deontological modus operandi that has critiqued White Christianity for its collusion with slavery, racism and colonialism whilst challenging Black Christianity to critical forms of resistance to White hegemony, promoting Black self determination and radical agency as its ethical riposte. ${ }^{14}$

\subsection{Black Christian Education}

Arguably, the single most important voice in the development of this tradition has been the late great Grant S. Shockley. ${ }^{15}$ Shockley was one of the early pioneers of Black, liberative approaches to Christian education and the socialization and Christian formation of African Americans. His work, which began in the 1960s and extended into the early 90s, was one of the first substantive attempts to re-orientate the very conceptualisation of Christian socialization and formation. Shockley outlined a five-stage implementation programme for a liberative model of Christian education for Black people. ${ }^{16}$ In the ongoing development of this work, Shockley asserts

9 See Hall (2009).

10 James H. Cone who is acknowledged as the founder of the systematic articulation of Black theology has argued convincingly that the discipline and its accompanying practice is committed to human liberation. See Cone (1990).

11 Gayraud S. Wilmore, one of the early titans of Black theology has argued that the discipline and practice is essentially pragmatic in its orientation. See Wilmore (2004).

12 James Cone asserts that most White theology that has emerged from White Christianity has led to indifference to the existence of racism and the suffering that this has exerted on Black people. See Cone (2004).

13 See Reddie (2009a).

14 See Cone (2004).

15 For the best scholarly appraisal of Shockely's life see Foster and Smith (2004).

16 Shockley (1987a, p. 31). 
The center of education for liberation occurs when persons are able to utilize their capacities of self-transcendence to evaluate reality, and as subjects, of naming the world instead of being named by it. ${ }^{17}$

An important and indeed necessary riposte to the bounded and restricted parameters set out by Western Christianity has been the fusing of Black theology and Christian education in the Black experience. Inspired by Shockely, my earliest pastoral and scholarly work was an attempt to combine Black theology and Christian education, in order to create a radical model of Christian learning that was predicated on liberative, pedagogical principles. ${ }^{18}$ Shockley argues that the process of learning about and being nurtured into the Christian faith for predominantly Diasporan Black people, should be concerned primarily with their holistic development, linking existential concerns with a liberative, biblical hermeneutic. ${ }^{19}$

Shockely, taking his cue from Black theology argues that the formational process, by which Black people learn to become Christians and the ideological framing of this pedagogical task, is one that should eschew the abstractions of doctrinal purity. Rather, the emphasis must be upon inculcating life skills, enabling Black people to navigate the perilous terrain created by White hegemony. ${ }^{20}$ Shockley is clear that for many, if not most Black people in the U.S (and in the UK also, in terms of Black people of African and Caribbean descent), our experience has been one of responding to the existential travails that have marked our troubled existence. ${ }^{21}$

Shockley's determination was that all models of Christian inspired teaching and learning should be contextual, liberative and relevant to the needs and realities of Black people. In arguing for the essential link between transformative models of pedagogy and Black theology, Shockley writes,

Black Theology has been instructive at the point of letting us know that any Religious education programme that might be constructed, must grow out of and center around the experiences, relationships and situational dilemmas that Black people face in their day to day struggle to survive, develop, and progress in an often hostile, uncaring majority-dominated society. ${ }^{22}$

In the context of this work, I believe a constant engagement with the seminal scholarship of Grant Shockely remains imperative, as he charts the essential building blocks for this modality of socialization and formation into the Christian faith. In effect, Shockley offers alternative constructs by which we might define the very nature and intent of Christianity. ${ }^{23}$

The development of Christian education for Black people that is focussed on personal development and social transformation has had to respond to the wider context of socio-political ferment, marginalization and oppression. Its birth and subsequent development was as a direct consequence of racism and colonial subjugation. Delores H. Carpenter argues that the Christian education of Black people in America has been a struggle against the historic forces of oppression. This Christian education struggle is linked to the fight for relevance and affirmation, and the parlous nature of this enterprise within an overall context of poverty and marginalization. ${ }^{24}$

In reconfiguring the nature and intent of Christianity post Donald Trump and Brexit, I am indebted to the inspirational work of Olivia Pearl Stokes, who along with Grant Shockley, is one of the pioneers of this transformative movement in liberative education. Stokes argues that the social tumult of the

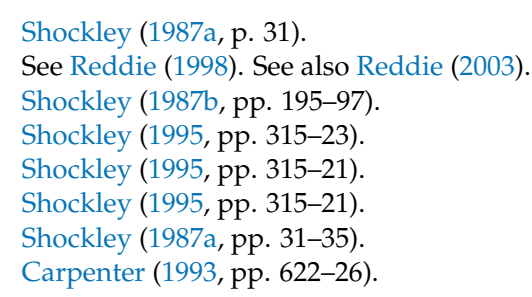


1960s was the impetus that gave rise to the development of liberationist modes of Christian learning and socialization. ${ }^{25}$ Stokes argues that

Thus education in the Black Church, with insights from Black theology, must become a part of that indispensable structure for survival and transformation that ameliorates these societal ills Christian faith is committed to remedy. ${ }^{26}$

Stokes' genius lay in her appreciation that religious education needed to be aligned to liberation theology, particularly, Black theology of liberation in order that the necessary enactment of liberative praxis is released within Black churches. At the time when the temptation was to see Christian religious education in purely pietistic terms, with emphasis placed on the inculcation of Christian doctrine and behavioural virtues, Stokes' brilliance was to re-envisage the very form and intent of religious pedagogy. Stokes believed that the significance of Christian religious education lay in its ability to conscientize Black people, helping them, like the emerging Black liberation theology, to see the gospel as indispensable to and consistent with their social condition. ${ }^{27}$

I am indebted to the editor of this special issue of Religious Education in reminding me of Stokes' towering importance to this field, as the first African American women to receive a doctorate in Religious Education in the United States. ${ }^{28}$ It can be argued that Olivia Pearl Stokes remains the unheralded architect of a liberative model of religious pedagogy that sowed the seeds for what was to emerge as the liberationist approaches to Black Christian socialization and formation, alongside Grant S. Shockley. ${ }^{29}$

Given our present epoch of rising White nationalism in The U.S. and across Europe, not forgetting Britain's challenge of dealing with Brexit, we need alternative constructs for conceiving the normative posture and archetypal exemplars for what constitutes Christianity.

\section{Participative Approaches Black Theological Pedagogy}

My own approach to linking transformative religious education and Black liberation theology has given rise to an interactive and participative mode of scholarly engagement. The roots of my approach to undertaking theological work was grounded in my formative development as a community educator working with poor, working class Black communities in Birmingham, in the West Midlands region of the UK. The significant factor in my intellectual and scholarly development has been the idiosyncratic journey I have taken in order to achieve this seemingly respectable nomenclature of an academic.

My initial development as a scholar arose from an interdisciplinary research project, during the course of which, I gained the confidence to devise improvisational techniques and approaches to theological reflection that intersect with the lived realities and subjectivities of predominantly ordinary Black people. ${ }^{30}$ This formative Black theological work was one that was conscious of the cultures, identities, historical and contemporary experiences and expressions of Christian faith within the socio-political and economic realities of inner city life in Britain. I have developed a form of scholarship that I have named 'Participative Black Theology'. Participative Black theology is the creative nexus between 'traditional' Black theology and Christian education. This approach to critical pedagogy has been refined over the years and has developed into an interdisciplinary mode of Practical, Black theological reflection.

At the heart of my Participative Black theology is the use of exercises and games that seek to enable participants to reflect critically on the self, and through the enaction of a central activity, they are

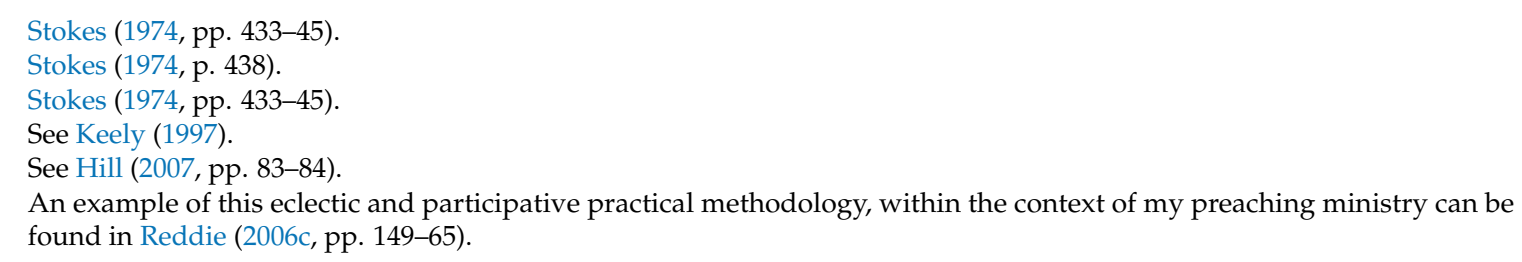


enabled to explore aspects of the theory and practice of Black theology in dialogue with others. In order to provide the grounding for the interactive, embodied, pedagogical engagement that lies at the heart of Participative Black theology, I have created a number of experiential exercises in which adult participants can explore the dynamics of encounters within a safe learning environment. The thrust for this work has emerged from previous pieces of research. ${ }^{31}$

My work as a Participative Black theologian seeks to develop models of Black theological reflection and learning that encapsulate the central tenets of Black Theology within a liberative pedagogical framework. My development as a scholar has been concerned with attempting to combine Christian education with Black theology in order to provide an accessible framework for the radical re-interpretation of the Christian faith for the transformation of ordinary people.

At the heart of Participative Black theology is the notion of 'Performative Action'. Performative action requires that we creatively engage with the 'other' in a socio-constructed space-often in a workshop setting - in which all participants promise to engage with the 'other' in a fashion that affirms mutuality, cooperation and a shared commitment to the production of new knowledge. $^{32}$ The production of new knowledge is not simply for the purposes of passing exams or writing term papers, ${ }^{33}$ rather, the desire is to create new forms of knowing for the express purpose of changing behaviour and developing better praxis in terms of Christian discipleship.

This process of performative action operates within often, informal workshop settings, in which I seek to create a safe space that affords predominantly ordinary lay people opportunities to reflect critically on the self and their engagement with others as Christian disciples within contexts and cultures that inform their experience as human beings. In this pedagogical approach to Black Participative theology I have used a variety of exercises and activities for enabling participants to explore their feelings and emotions in a safe space. The exercises allow them to adopt imaginary roles and to 'park' their sometimes 'extreme' feelings within a comparatively safe 'rest area' where they can notionally ascribe responsibility for their anger, frustration or sense of tension to the fictional persona of the character they have adopted in the exercise.

The use of a participative approach to Black theology, linked with Christian education, for the purposes of encouraging adult learners to engage in anti-racial models of Christian discipleship; is one that uses Martin Luther King Jnr's notion of the 'Beloved Community' 34 as its central heuristic. The use of exercises and drama represents an invitation for adult learners to reflect within the hospitable and safe space of the workshop. In this context, they can explore and commit themselves to working for and becoming a part of the collective spiritual and psychological journey of the Christian church, towards the 'promised land' of racial justice. What in effect, I would describe as the 'Reign of God', or 'God's gracious economy'. ${ }^{35}$

In the various exercises, participants, by means of conversation and interaction, have the opportunity to reflect on their action within the context of a central activity, and to assess their agency and responses to it for its truthfulness to God's gracious activity in Jesus Christ, when juxtaposed with the historical and contemporary experience of racism and oppression. ${ }^{36}$

The participative element of the work challenges learners to decide how they will inhabit particular spaces and places in order to assess in what ways are they playing out learnt pathologies that

31 See Reddie $(2005,2006 a)$.

32 See Irizarry (2003, pp. 365-81); See also Apt (1970).

33 These workshops are usually not assessed nor are students tested on the learning they have accrued during the day, so this work is very much located in the affective development of lay people and not in their evaluated cognitive learning.

34 See Baldwin (1995).

35 I am very much indebted to my friend and colleague Michael N. Jagessar for the latter term or phrase for naming the eschatological hope of God's justice and equity for all persons that constitutes our futuristic hope within the Christian faith. See Jagessar (1997).

36 See Andrews (2014, pp. 11-29). 
are often informed by the specious binaries of 'them' and 'us'? ${ }^{37}$ What would happen, if participants were enabled to take on the persona of the 'other' in order to live out their realities and experiences within a participative exercise? To what extent would these experiences change their subjective self and their concomitant consciousness?

The journey towards the beloved community is one in which the process is as important as the destination that is reached. In the context of performative action, one is constantly challenging participants to question their assumptions on what is deemed to be 'normative' and that which is termed as 'aberrant' or 'transgressive'. The modus operandi of this approach to undertaking Participative Black theology is for the purpose of offering participants new models of being Christian in a context where White nationalism and racism is on the rise. ${ }^{38}$

The purpose of this approach to undertaking Black Theology lies in the belief that internalised change (spiritual and psychological) can be a conduit for externally, verified changes in behaviour and practice. Both of these modes provide the subjective, experiential basis for liberation, at an individual, inter-personal, communal and ultimately, a systemic level.

The use of participative exercises creates a scholarly connectivity between, on the one hand, teaching and learning that conscientizes students in the classroom and, on the other hand, the creation of new knowledge within the wider purview of practical theological exploration. This model of liberative, pedagogical work is predicated on a participative teaching and learning process. The natural corollary of this pedagogical approach is a model of liberative theological reflection that is undertaken by means of participative exercises through which new theories and concepts for Christian praxis are enacted.

In these participative workshops, I have often used a particular experiential exercise as a way of enabling White students, for example, to reflect on the powerful but hidden normative strength of Whiteness. ${ }^{39}$ The exercises often work as a form of liberative pedagogy that explores theological anthropology among people engaged in various forms of Christian ministry. I would like to describe, briefly, a particular exercise I have developed, in order to demonstrate the pedagogical approach to Participative Black theology.

The exercise begins with each participant receiving a piece of paper on which is printed a series of four concentric circles. The participants look at the innermost circle and are asked to put down one term, or at most two, that define them. This term is central to how they see themselves at that moment. It may be factual (male, female, man, woman) or it may be a characteristic (kind or loving), or a relational term (mother, uncle, child of God) or generic (human being), or something else. I try not to say too much, for fear of suggesting what the participants might name. The term is located in the innermost circle as it is most central or most important to how that individual understands themselves as a human being.

The exercise continues with successive movements out from the central circle, with the participants invited to put down further terms that define them. When different terms have been placed in all the circles, I ask participants to share what they have listed. Is there anything immediate to note about where particular terms have been placed? The exercise is a practical, experiential-participative form of pedagogy for exploring the theological subjectivity of Christian disciples. The exercise combines participative, experiential pedagogy and Black liberation theology in order to challenge participants to reflect critically on what it means to claim that we are created in the image of God. African American Black theologian Dwight Hopkins has shown that being a Black human being is a concept that is both

37 African American Womanist theologian Kelly Brown Douglas demonstrates the extent to which binary notions of 'in groups' and 'out groups' within Christian communities can be traced back to the notion of a 'Closed Monotheism' within Judaeo-Christian theologies of the Hebrew Bible and the New Testament. See Douglas (2005).

38 See the following website Where the Then Leader of UKIP (n.d.).

39 Reddie (2009b, pp. 37-52). 
complex and often illusory. ${ }^{40}$ Black and Womanist theologians have repeatedly argued that one cannot take as axiomatic any sense of what it means to be a Black human being that has not in itself been both a bold, critical act of self-assertion and a determined act of will. ${ }^{41}$

When asking participants to reflect on the terms they have used in the exercise, I have often found it illuminating to ask what is not stated by those terms. I have used this exercise on myself on many occasions, most usually when carrying it out with others in a workshop setting. I have a golden rule of never asking anyone to do something I am not prepared to do myself, and I therefore ensure that I also complete the exercise.

The exercise enables me to undertake the task of conscientizing students in forms of theological reflection that engage with issues of race, identity, power and context, in Christian ministry and discipleship. This method is a form of participative, liberative pedagogy that enables students to explore theological anthropology as a form of social inquiry. ${ }^{42}$

This and other exercises have been used to enable students to reflect critically on their experience in learning about and being immersed into Participative Black theology, but also seeks to provide them with opportunities to undertake their own research projects. ${ }^{43}$ So, for example, I have encouraged students to use this participative piece of work to undertake their own forms of qualitative research, particularly into contextual theological anthropology in practical theology.

As a practical theologian, I am eager that all participants in the workshops become anti-racist Christians committed to living out a radical and liberative faith that means standing alongside others in solidarity against injustice. In particular, I want White participants to become Christian activists who will resist the toxic tentacles of racism.

\section{Conclusions}

In the final analysis, this overarching approach to liberative pedagogy is one that recognizes the significance of personal, subjective, and affective learning as a conduit for a transformative, anti-racist practice of Christian discipleship. It utilizes a critical nexus of liberative pedagogy and participative Black theological reflection via performative forms of action, in order to raise the critical consciousness of learners and so bring about new forms of embodied, liberationist inspired models of Christian praxis.

The learning that emerges from these creative and critical encounters enables participants to reflect on their own embodied subjectivity in order to be cognizant of self and thus engage in a more informed manner with the 'Other'. It is my contention that the subjective and experiential basis of this approach to anti-racist Christian discipleship lies at the heart of the God who makes Godself known in personal encounters with all people, through the humanity of Jesus, in the power of the Holy Spirit.

Given our present epoch of rising White nationalism in The U.S. and across Europe, and not forgetting Britain's challenge of dealing with Brexit, we need alternative constructs for conceiving the normative posture and archetypal exemplars for what constitutes Christianity. It is my belief that this model of religious education can be the conduit for alternative modes of Christian formation. This approach to Christian formation is not predicated on an axiomatic understanding of Christian discipleship that is reflected in the concealed and tacit notions of White normativity, in which Whiteness comes to represent the embodied ideal for notions of belonging. Conversely, transformative models of Christian education in the Black experience are forms of liberative, faith based pedagogy whose focus is on marginalized Black bodies in which the crucified Christ is revealed. This work draws on the radical tradition of Christian education pioneered by African Americans since the late 60s, which has been augmented by my own developing work in Participative Black theology. This work is committed to radical subjective change in the Christian discipleship of ordinary people, in the belief that authentic,

\footnotetext{
Hopkins (2005, pp. 1-52).

1 Townes (2006).

42 I have developed a number of these forms of experiential exercises in a number of books. See Reddie $(1998,2005,2012)$.

See also the following by Reddie (2006a, 2008, 2009b).
} 
socio-political transformation begins from the bottom-up. It is a form of socio-political theo-pedagogy that informed my life for the past twenty or so years and to which, I imagine, I will continue to devote my energies in the years to come.

Funding: This research received no external funding.

Conflicts of Interest: The author declares no conflict of interest.

\section{References}

Andrews, Dale P. 2014. African American Practical Theology. In Opening the Field of Practical Theology: An Introduction. Edited by Kathleen A. Cahalan and Gordon S. Mikoski. New York: Roman and Littlefield. Apt, Clark C. 1970. Serious Games. New York: Viking Press.

Astley, Jeff, Leslie J. Francis, and Colin Crowder, eds. 1996. Theological Perspectives on Christian Formation. Leominster: Gracewings, Grand Rapids: Eerdmans.

Baldwin, Lewis V. 1995. Toward the Beloved Community. Cleveland: The Pilgrim Press.

Carpenter, Delores H. 1993. A Response to Brian Tippen. Religious Education 88: 622-26.

Cone, James. 1990. A Black Theology of Liberation. New York: Maryknoll.

Cone, James H. 2004. Theology's Great Sin: Silence in the Face of White Supremacy. Black Theology: An International Journal 2: 139-52. [CrossRef]

Douglas, Kelly Brown. 2005. What's Faith Got to Do with It? Black Bodies/Christian Souls. Marknoll: Orbis Books.

Foster, Charles R., and Fred Smith. 2004. Black Religious Experience: Conversations on Double Consciousness and the Work of Grant Shockley. Nashville: Abingdon Press.

Freire, Paulo. 1993. Pedagogy of the Oppressed. New York: Herder and Herder. First published 1970.

Freire, Paulo. 1990. Education for Critical Consciousness. New York: Continuum. First published 1973.

Freire, Paulo. 1999. A Pedagogy of Hope: Relieving Pedagogy of the Oppressed. New York: Continuum.

Hall, Delroy. 2009. The Middle Passage as Existential Crucifixion. Black Theology: An International Journal 7: 45-63. [CrossRef]

Hill, Kenneth H. 2007. Religious in the African American Tradition: A Comprehensive Introduction. St. Louis: Chalice Press.

Hope, Anne, Sally Timmel, and Chris Hodzi. 1994. Teaching for Transformation: A Handbook for Community Workers. Books 1-3. Gweru: Mambo Press.

Hope, Anne, Sally Timmel, and Chris Hodzi. 1999. Teaching for Transformation: A Handbook for Community Workers. Book 4. London: Intermediate Technology Publication LTD.

Hopkins, Dwight N. 2005. Being Human: Race, Culture and Religion. Minneapolis: Fortress.

Irizarry, Jose. 2003. The Religious educator as Cultural Spec-Actor: Researching Self in Intercultural Pedagogy. Religious Education [The Vocation of the Religious Educator] 98: 365-81. [CrossRef]

Jagessar, Michael N. 1997. Full Life for All: The Work and Theology of Philip A. Potter: A Historical Survey and Systematic Analysis of Major Themes. Zoetermeer: Boekencentrum.

Keely, Barbara Anne. 1997. Faith of Our Foremothers: Women Changing Religious Education. Louisville: Westminster John Knox Press.

Moore, Allen J. 1989. A Social Theory of Religious Education. In Religious Education as Social Transformation. Birmingham: Religious Education Press.

Reddie, Anthony. 1998. Growing into Hope: Christian Education in Multi-Ethnic Churches. 2 Volumes (Volume 1: Believing and Expecting; Volume 2 Liberation and Change). Peterborough: Methodist Publishing House.

Reddie, Anthony G. 2003. Nobodies to Somebodies: A Practical Theology for Education and Liberation. Peterborough: Epworth Press.

Reddie, Anthony G. 2005. Acting in Solidarity: Reflections in Critical Christianity. London: DLT.

Reddie, Anthony G. 2006a. Dramatizing Theologies: A Participative Approach to Black God-Talk. London: Equinox.

Reddie, Anthony G. 2006b. Black Theology in Transatlantic Dialogue. Basingstoke \& New York: Springer.

Reddie, Anthony G. 2006c. An Interactive Odyssey. In Pulpit Journeys. Edited by Geoffrey Stevenson. London: DLT.

Reddie, Anthony G. 2008. Working against the Grain: Re-Imaging Black Theology in the 21st Century. London: Equinox.

Reddie, Anthony G. 2009a. Not Just Seeing, but Really Seeing: A Practical Black Liberationist Spirituality for Re-interpreting Reality. Black Theology: An International Journal 7: 339-65. [CrossRef] 
Reddie, Anthony G. 2009b. Is God Colour Blind? Reflections on Black Theology for Christian Ministry. London: SPCK. Reddie, Anthony. 2012. SCM Core Text: Black Theology. London: SCM.

Shockley, Grant S. 1987a. Black Pastoral Leadership in Religious Education. In The Pastor as Religious Educator. Edited by Robert L. Browning. Birmingham: Religious Education Press.

Shockley, Grant S. 1987b. Christian Education and the Black Religious Experience. In Ethnicity in the Education of the Church. Edited by Charles R. Foster. Nashville: Conference Papers/Scarritt Graduate School, Scarritt Press.

Shockley, Grant S. 1995. Black Theology and Religious Education. In Theologies of Religious Education. Edited by Randolph Crump Miller. Birmingham: Religious Education Press.

Stokes, Olivia Pearl. 1974. Education in the Black Church: Design for Change. Religious Education 69: $433-45$. [CrossRef]

Townes, Emile M. 2006. Womanist Ethics and the Cultural Production of Evil. New York: Palgrave Macmillan.

Where the Then Leader of UKIP, Nigel Farage, Clearly Invokes a Cultural Interpretation of Christianity as a Means of Promoting a Reactionary, Homogeneous Construct of Britain. Available online: http:/ / www.secularism. org.uk/news /2015/04/nigel-farage-calls-for-muscular-defence-of-christianity-in-the-uk (accessed on 9 February 2017).

Wilmore, Gayraud S. 2004. Pragmatic Spirituality: The Christian Faith through an Africentric Lens. New York: New York University Press.

(c) 2018 by the author. Licensee MDPI, Basel, Switzerland. This article is an open access article distributed under the terms and conditions of the Creative Commons Attribution (CC BY) license (http://creativecommons.org/licenses/by/4.0/). 